Article

\title{
New Insight into the Influence of Rhamnolipid Bio-Surfactant on the Carbonate Rock/Water/Oil Interaction at Elevated Temperature
}

\author{
Sina Rezaei Gomari * (D), Kamal Elyasi Gomari, Meez Islam and David Hughes \\ School of Science, Engineering and Design, Teesside University, Middlesbrough TS1 3BX, UK; \\ S6163285@tees.ac.uk (K.E.G.); M.Islam@tees.ac.uk (M.I.); D.J.Hughes@tees.ac.uk (D.H.) \\ * Correspondence: s.rezaei-gomari@tees.ac.uk; Tel.: +44-784-701-2063
}

Received: 11 October 2018; Accepted: 8 November 2018; Published: 16 November 2018

check for updates

\begin{abstract}
Tertiary recovery is directly dependent on the alteration in wettability and interfacial tension (IFT), hence releasing the trapped oil from rock pore spaces. Bio-surfactant water flooding to mobilise residual oil in reservoirs is a new and developing prospect that can be used more often in future due to its environmentally friendly nature and economic advantages. In this work, the impact of rhamnolipids as water soluble bio-surfactant solutions on the interfacial activities of saline water and the wettability of carbonate rock are studied at elevated temperature. The effectiveness of the bio-surfactant as a rock wettability modifier is analysed in the presence of different salinities, in particular $\mathrm{SO}_{4}{ }^{2-}$ ions. The reason for the focus on $\mathrm{SO}_{4}{ }^{2-}$ is its high affinity towards calcite surfaces, and hence its ability to intervene strongly on bio-surfactant performance. To achieve the objectives of this study, the oil-wet calcite samples at elevated temperature were put through a washing process that included bio-surfactant solutions in seawater at various concentrations of sodium sulphate ions, where the measurement of the contact angles of each sample after treatment and the IFT between the oil model and the washing solutions were taken. The obtained results illustrated that bio-surfactants (rhamnolipids) with incremental concentrations of $\mathrm{SO}_{4}{ }^{2-}$ ions in sea water (up to three times higher than the original ion concentration) can lower the IFT, and assessed changing the rocks towards greater water-wettability. This study reveals that the alteration of $\mathrm{SO}_{4}{ }^{2-}$ ions had a greater impact on the wettability alteration, whereas rhamnolipids were better at reducing the IFT between the oil phase and the aqueous phase. This study also looked at temperatures of $50{ }^{\circ} \mathrm{C}$ and $70^{\circ} \mathrm{C}$, which demonstrated undesired influences on the wettability and IFT. Bio-surfactants at high temperature showed less interfacial activity, thus indicating that rhamnolipids are not active at high temperatures, while the addition of $\mathrm{SO}_{4}{ }^{2-}$ shows a continuous decrease in the contact angle and IFT measurements at high temperature.
\end{abstract}

Keywords: carbonate rock; bio-surfactant; rhamnolipids; wettability; contact angle; sulphate ions; elevated temperature; IFT

\section{Introduction}

With the world's energy demands growing, oil recovery has become a global priority. The development of oil extraction techniques has gradually changed and improved in order to increase oil recovery. Worldwide, oil production only recovers on average about a third of the oil originally present in reservoirs, which is the amount of oil recovered economically using conventional methods. The remaining two-thirds of residual oil in the reservoirs is the focus of Enhanced Oil Recovery (EOR) methods [1].

Microbial enhanced oil recovery (MEOR) represents the use of microbes in oil recovery, which is a tertiary EOR technique still under development. MEOR is widely appropriate in carbonate and 
sandstone reservoirs for both light and heavy crude oil. MEOR has been proposed as an effective and cheap alternative for EOR, and involves utilising the metabolic products the microorganisms produce to aid the oil production. In general, there are seven types of bioproducts, which include biopolymers, bio-surfactants, biomass, solvents, acids, emulsifiers, and gases. It is noted that bio-surfactants are more attractive compared to other bioproducts due to their low toxicity, stability, and impact on the wettability alteration to increase enhanced oil recovery [2].

Bio-surfactants are amphiphilic, consisting of both hydrophobic and hydrophilic parts. Bio-surfactants have the potential to lower the surface and interfacial tension (IFT) by gathering at the interface between the two immiscible fluids. This reduces the repulsive forces and allows the two phases to interact and mix more easily; it also improves the mobility and solubility of the insoluble or hydrophobic organic compounds [3,4].

Rhamnolipids are a type of bio-surfactant that are produced mainly by Pseudomonas aeruginosa. It should be noted that because of their low toxicity, production from renewable sources, and antimicrobial (particularly antifungal) activity, the use of rhamnolipid bio-surfactants shows great promise for broad commercial application [5].

The concentration of a bio-surfactant is effective until the critical micelle concentration (CMC) is obtained. CMC is associated with micelle formation, which allows bio-surfactants to reduce the IFT and increase the solubility and bioavailability of a hydrophobic compound. CMC is known as the efficiency of the bio-surfactant, where less bio-surfactant is required to lower the IFT; an effective bio-surfactant will have a low CMC [6]. The remaining oil residual in reservoirs is generally located in restricted access regions where oil is trapped in pores by capillary pressure. Bio-surfactants can lower the IFT between oil/rock and water/oil and also alter the wettability to water-wet the system-this reduces the capillary forces, which allows water to move through the rock pores [7].

Al-Sulaimani et al. [8] found that the maximum production of residual oil went up by $50 \%$ by using bio-surfactant and chemical surfactant in a 50:50 mixing ratio. The study also looked at the influence of the bio-surfactant on the wettability of calcite surface by studying contact angle measurements. The results showed that a $0.25 \%$ treated $(w / v)$ bio-surfactant solution changed to greater water-wetting as the angle decreased from 70.6 to $25.32^{\circ}$. Other studies [9-11] presented similar trends in the use of different bio-surfactants for the displacement of oil by water.

Wettability tests performed on carbonate reservoirs at elevated temperature have showed that increasing temperatures alter the wettability towards greater water-wetting, which was attributed to the de-attachment of oil-wet particles (i.e., calcium stearate) from the calcite surface, making the surface more water-wet [12-14]. In general, wettability and IFT are considered to be the main controlling parameters of fluid flow in carbonate rocks, particularly for high temperature reservoir conditions.

Water salinity has also been shown to have a significant impact via an increase of the capillary force, lowering of the IFT, and altering of the wettability of carbonate reservoirs $[15,16]$. Seawater is an example of brine water that contains different active ions such as calcium $\left(\mathrm{Ca}^{2+}\right)$, magnesium $\left(\mathrm{Mg}^{2+}\right)$, and sulphate $\left(\mathrm{SO}_{4}{ }^{2-}\right)$ ions $[17,18]$. By injecting brine water into the rock fracture, $\mathrm{SO}_{4}{ }^{2-}$ ions are adsorbed onto the positive calcite surface. This decreases the rock positive charges, which also reduces the electrostatic repulsion, thereby allowing cation ions to move closer to the surface. The presence of cation ions will bind with the negatively charged carboxylic acids and remove them from the rock surface. As the temperature increases, the concentration of $\mathrm{Ca}^{2+}$ and $\mathrm{SO}_{4}{ }^{2-}$ near the surface increases, increasing the efficiency of the displacement of carboxylic groups. The removal of adsorbed carboxylic groups from the rock surface reduces the capillary forces, which improves oil recovery [19].

The main objective of this research was to assess the alteration in wettability of modified oil-wet calcium carbonate and IFT reduction under the influence of bio-surfactants. Moreover, this study investigated the effectiveness of bio-surfactants in the wetting alteration process as well as the fluid/fluid interfacial tension in the presence of most active sulphate ions at elevated temperature. 


\section{Materials and Methods}

\subsection{Chemicals, Solvents, and Bio-Surfactants}

All the salt chemicals $\left(\mathrm{CaCO}_{3}, \mathrm{NaCl}, \mathrm{Na}_{2} \mathrm{SO}_{4}, \mathrm{KCl}, \mathrm{NaHO}_{3}, \mathrm{KBr}, \mathrm{MgF}_{2}, \mathrm{CaCl}_{2}\right.$, and $\left.\mathrm{SrCl}_{2}\right)$, n-decane, stearic acid and calcite powder were supplied by Sigma-Aldrich. Stearic acid was used as a surface-active additive in n-decane to produce model oil resembling crude oil. Calcite powder with $99 \%$ purity was used to represent the carbonate rock reservoirs. Water soluble rhamnolipids, the bio-surfactant dominant form of dirhamnolipid, provided by the TeeGene Company (Teesside, UK), was added to the water solutions to study its application in EOR [20]. Different water compositions in the presence and absence of bio-surfactants were used as washing solutions to investigate their ability to wash out the adsorbed stearic acid from calcite surface. Table 1 presents the compositions of the washing solutions.

Table 1. Composition of washing solutions. Distilled water was considered as a reference and called $\mathrm{WS}_{1}$. WS $\mathrm{W}_{5}$ solution was made by adding $73 \mathrm{mg} / \mathrm{L}$ of the bio-surfactant to distilled water [20]. The base for the rest of the solutions was artificial sea water [21].

\begin{tabular}{|c|c|c|c|c|c|c|c|}
\hline $\begin{array}{c}\text { Additives to } \\
\text { Distilled Water }\end{array}$ & $\begin{array}{c}\mathrm{WS}_{2} \mathrm{~g} / \mathrm{kg} \\
\text { of } \\
\text { Distilled } \\
\text { Water }\end{array}$ & $\begin{array}{c}\mathrm{WS}_{3} \mathrm{~g} / \mathrm{kg} \\
\text { of } \\
\text { Distilled } \\
\text { Water }\end{array}$ & $\begin{array}{c}\mathrm{WS}_{4} \mathrm{~g} / \mathrm{kg} \\
\text { of } \\
\text { Distilled } \\
\text { Water }\end{array}$ & $\begin{array}{c}\mathrm{WS}_{5} \mathrm{~g} / \mathrm{kg} \\
\text { of } \\
\text { Distilled } \\
\text { Water }\end{array}$ & $\begin{array}{c}\mathrm{WS}_{6} \mathrm{~g} / \mathrm{kg} \\
\text { of } \\
\text { Distilled } \\
\text { Water }\end{array}$ & $\begin{array}{c}\mathrm{WS}_{7} \mathrm{~g} / \mathrm{kg} \\
\text { of } \\
\text { Distilled } \\
\text { Water }\end{array}$ & $\begin{array}{c}\mathrm{WS}_{8} \mathrm{~g} / \mathrm{kg} \\
\text { of } \\
\text { Distilled } \\
\text { Water }\end{array}$ \\
\hline $\mathrm{Cl}^{-}$ & 19.353 & 19.353 & 19.353 & 0 & 19.353 & 19.353 & 19.353 \\
\hline $\mathrm{Na}^{+}$ & 10.765 & 10.765 & 10.765 & 0 & 10.765 & 10.765 & 10.765 \\
\hline $\mathrm{SO}_{4}{ }^{2-}$ & 2.711 & 5.422 & 8.133 & 0 & 2.711 & 5.422 & 8.133 \\
\hline $\mathrm{Mg}^{2+}$ & 1.295 & 1.295 & 1.295 & 0 & 1.295 & 1.295 & 1.295 \\
\hline $\mathrm{Ca}^{2+}$ & 0.414 & 0.414 & 0.414 & 0 & 0.414 & 0.414 & 0.414 \\
\hline $\mathrm{K}^{+}$ & 0.387 & 0.387 & 0.387 & 0 & 0.387 & 0.387 & 0.387 \\
\hline $\mathrm{HCO}_{3}{ }^{-}$ & 0.142 & 0.142 & 0.142 & 0 & 0.142 & 0.142 & 0.142 \\
\hline $\mathrm{Br}^{-}$ & 0.066 & 0.066 & 0.066 & 0 & 0.066 & 0.066 & 0.066 \\
\hline $\mathrm{Sr}^{2+}$ & 0.008 & 0.008 & 0.008 & 0 & 0.008 & 0.008 & 0.008 \\
\hline $\mathrm{H}_{3} \mathrm{BO}_{3}$ & 0.026 & 0.026 & 0.026 & 0 & 0.026 & 0.026 & 0.026 \\
\hline $\mathrm{F}^{-}$ & 0.001 & 0.001 & 0.001 & 0 & 0.001 & 0.001 & 0.001 \\
\hline $\begin{array}{c}\text { Added } \\
\text { Bio-Surfactant } \\
\text {-Rhamnolipids }\end{array}$ & 0 & 0 & 0 & $0.073 \mathrm{~mL}$ & $0.073 \mathrm{~mL}$ & $0.073 \mathrm{~mL}$ & $0.073 \mathrm{~mL}$ \\
\hline
\end{tabular}

\subsection{Sample Preparations}

\subsubsection{Modification of Water-Wet Calcite to Oil-Wet Calcite}

In order to produce an oil-wet calcite surface resembling oil reservoir conditions, calcite rock was treated with dissolved polar components in the model oil. To this end, first $500 \mathrm{~mL}$ of $\mathrm{n}$-decane was added to $1.42 \mathrm{~g}$ of stearic acid to make a $0.01 \mathrm{M}$ concentration. Afterwards, $80 \mathrm{~mL}$ of oil model was mixed with $20 \mathrm{~g}$ of calcite powder within a conical flask. Then, the conical flask was placed into a hot plate stirrer at a speed of $50 \mathrm{rpm} / \mathrm{min}$ stirring for $24 \mathrm{~h}$ to collect the filtered liquid. Finally, calcite powder was transferred into a beaker oven at a temperature of $40^{\circ} \mathrm{C}$ for $24 \mathrm{~h}$ to dry and solidify.

\subsubsection{Wash Solution Preparation}

To determine the effect of active ions such as $\mathrm{SO}_{4}{ }^{2-}$ as well as the bio-surfactant (rhamnolipids) on oil-wet calcite, different forms of wash solutions (WS) were made to wash the modified calcite, which is listed in Table 2, with distilled water as a reference $\mathrm{WS}_{1}$. The compositions are presented in Table 1. 
Table 2. Wash solution label description.

\begin{tabular}{|c|c|}
\hline Wash Solution Label & Wash Solution Name \\
\hline $\mathrm{WS}_{1}$ & Distilled water \\
\hline $\mathrm{WS}_{2}$ & Seawater (composition found in Kester, et al., 1967 [21]) \\
\hline $\mathrm{WS}_{3}$ & Seawater with $2 \mathrm{X} \mathrm{SO}_{4}{ }^{2-}$ \\
\hline $\mathrm{WS}_{4}$ & Seawater with $3 \mathrm{X} \mathrm{SO}_{4}{ }^{2-}$ \\
\hline $\mathrm{WS}_{5}$ & Distilled water + Bio-surfactant \\
\hline $\mathrm{WS}_{6}$ & Seawater + Bio-surfactant \\
\hline $\mathrm{WS}_{7}$ & Seawater with $2 \mathrm{X} \mathrm{SO}_{4}{ }^{2-}+$ Bio-surfactant \\
\hline $\mathrm{WS}_{8}$ & Seawater with $3 \mathrm{X} \mathrm{SO}_{4}{ }^{2-}+$ Bio-surfactant \\
\hline
\end{tabular}

\subsubsection{Washing Process of Modified Calcite}

In order to determine the effect of the saline solution and the bio-surfactant on the calcite surface, a washing process of the modified calcite was performed. First, $4 \mathrm{~g}$ of modified calcite and $20 \mathrm{~mL} \mathrm{WS}_{1}$ were mixed into a beaker. Then, the beaker was placed on a hot plate stirrer at a speed of $50 \mathrm{rpm} / \mathrm{min}$ stirring for $48 \mathrm{~h}$ to collect the filtered liquid. Finally, the beaker was placed in a vacuum oven at a temperature of $40^{\circ} \mathrm{C}$ for $24 \mathrm{~h}$ for the solid to completely dry. All these processes were done for the remaining of $\mathrm{WS}_{2}-\mathrm{WS}_{8}$ solution.

\subsection{Contact Angle Measurement}

To measure the contact angle, the calcite powder was crushed into fine granular forms and then pressed into small disks that provided the samples with a flat and smooth surface for accurate contact angle measurement when the water droplet could come into contact with the powder surface. Finally, the disk was placed on a Kruss DSA 100 Goniometer analyser (KRÜSS GmbH, Hamburg, Germany) with distilled water released on the surface to measure the contact angle at room temperature of modified calcite sample and samples treated (washed) with three different temperatures. Table 3 presents a list of selected samples with different wash solutions at three different temperatures for contact angle measurement.

Table 3. Selected treated samples with different wash solutions at three different temperatures for contact angles.

\begin{tabular}{ccc}
\hline Wash Solution & Temperature & Label \\
\hline$W_{1}$ & $25^{\circ} \mathrm{C}$ & $\mathrm{K}_{1}$ \\
$\mathrm{WS}_{2}$ & $25^{\circ} \mathrm{C}$ & $\mathrm{K}_{2}$ \\
$\mathrm{WS}_{5}$ & $25^{\circ} \mathrm{C}$ & $\mathrm{K}_{3}$ \\
$\mathrm{WS}_{6}$ & $25^{\circ} \mathrm{C}$ & $\mathrm{K}_{4}$ \\
$\mathrm{WS}_{3}$ & $25^{\circ} \mathrm{C}$ & $\mathrm{K}_{5}$ \\
$\mathrm{WS}_{4}$ & $25^{\circ} \mathrm{C}$ & $\mathrm{K}_{6}$ \\
\hline \multirow{2}{*}{$\mathrm{WS}_{1}$} & $50^{\circ} \mathrm{C}$ & $\mathrm{K}_{7}$ \\
& $70^{\circ} \mathrm{C}$ & $\mathrm{K}_{8}$ \\
\hline \multirow{2}{*}{$\mathrm{WS}_{2}$} & $50^{\circ} \mathrm{C}$ & $\mathrm{K}_{9}$ \\
& $70^{\circ} \mathrm{C}$ & $\mathrm{K}_{10}$ \\
\hline \multirow{2}{*}{$\mathrm{WS}_{5}$} & $50^{\circ} \mathrm{C}$ & $\mathrm{K}_{11}$ \\
& $70^{\circ} \mathrm{C}$ & $\mathrm{K}_{12}$ \\
\hline & $25^{\circ} \mathrm{C}$ & $\mathrm{K}_{13}$ \\
$W_{7}$ & $50^{\circ} \mathrm{C}$ & $\mathrm{K}_{14}$ \\
& $70^{\circ} \mathrm{C}$ & $\mathrm{K}_{15}$ \\
\hline & $25^{\circ} \mathrm{C}$ & $\mathrm{K}_{16}$ \\
$W_{3}$ & $50^{\circ} \mathrm{C}$ & $\mathrm{K}_{17}$ \\
& $70^{\circ} \mathrm{C}$ & $\mathrm{K}_{18}$ \\
\hline
\end{tabular}




\subsection{Interfacial Tension Measurement}

To carry out the required experiments for the IFT measurements, the Du Nouy ring method using a Kruss Digital Tensiometer Model K9 (KRÜSS GmbH, Hamburg, Germany) was utilised. First, $10 \mathrm{~mL}$ of model oil and $10 \mathrm{~mL}$ of wash solution were mixed into a beaker and then heated with a hot plate stirrer. After that, the mixtures of the model oil and washing solution were transferred into special glassware to measure the IFT (Table 4).

Table 4. Mixture label description.

\begin{tabular}{cccc}
\hline Mixtures Label & Oil Mixture & Wash Solution & Temperature \\
\hline $\mathrm{M}_{1}$ & N-decane & $\mathrm{WS}_{1}$ & $25^{\circ} \mathrm{C}$ \\
$\mathrm{M}_{2}$ & Dissolved steric acid + n-decane & $\mathrm{WS}_{1}$ & $25^{\circ} \mathrm{C}$ \\
$\mathrm{M}_{3}$ & Dissolved steric acid + n-decane & $\mathrm{WS}_{2}$ & $25^{\circ} \mathrm{C}$ \\
$\mathrm{M}_{4}$ & Dissolved steric acid + n-decane & $\mathrm{WS}_{3}$ & $25^{\circ} \mathrm{C}$ \\
$\mathrm{M}_{5}$ & Dissolved steric acid + n-decane & $\mathrm{WS}_{4}$ & $25^{\circ} \mathrm{C}$ \\
$\mathrm{M}_{6}$ & Dissolved steric acid + n-decane & $\mathrm{WS}_{5}$ & $25^{\circ} \mathrm{C}$ \\
$\mathrm{M}_{7}$ & Dissolved steric acid + n-decane & $\mathrm{WS}_{6}$ & $25^{\circ} \mathrm{C}$ \\
$\mathrm{M}_{8}$ & Dissolved steric acid + n-decane & $\mathrm{WS}_{7}$ & $25^{\circ} \mathrm{C}$ \\
$\mathrm{M}_{9}$ & Dissolved steric acid + n-decane & $\mathrm{WS}_{8}$ & $25^{\circ} \mathrm{C}$ \\
$\mathrm{M}_{10}$ & Dissolved steric acid + n-decane & $\mathrm{WS}_{5}$ & $50^{\circ} \mathrm{C}$ \\
$\mathrm{M}_{11}$ & Dissolved steric acid + n-decane & $\mathrm{WS}_{7}$ & $50^{\circ} \mathrm{C}$ \\
$\mathrm{M}_{12}$ & Dissolved steric acid + n-decane & $\mathrm{WS}_{8}$ & $50^{\circ} \mathrm{C}$ \\
$\mathrm{M}_{13}$ & Dissolved steric acid + n-decane & $\mathrm{WS}_{5}$ & $70^{\circ} \mathrm{C}$ \\
$\mathrm{M}_{14}$ & Dissolved steric acid + n-decane & $\mathrm{WS}_{7}$ & $70^{\circ} \mathrm{C}$ \\
$\mathrm{M}_{15}$ & Dissolved steric acid + n-decane & $\mathrm{WS}_{8}$ & $70^{\circ} \mathrm{C}$ \\
\hline
\end{tabular}

\section{Results and Discussion}

\subsection{Contact Angle Measurement}

Three water droplets were used and repeated on different sections of the disk surface with at least three readings taken for each droplet, which produced an accurate average contact angle for each sample. Table 5 shows the contact angle of a modified sample before any additive are used.

Table 5. Contact angle measurement on modified calcite before contact with any washing solutions.

\begin{tabular}{|c|c|c|c|c|c|}
\hline \multicolumn{6}{|c|}{ Modified Calcite } \\
\hline \#Attempt & Reading $1\left(^{\circ}\right)$ & Reading $2\left(^{\circ}\right)$ & Reading $3\left(^{\circ}\right)$ & Average Reading Contact Angle $\left({ }^{\circ}\right)$ & Wetting System \\
\hline $\begin{array}{c}\text { Water } \\
\text { Droplet } 1\end{array}$ & 108.6 & 108.3 & 109.4 & 108.8 & Oil-Wet \\
\hline $\begin{array}{c}\text { Water } \\
\text { Droplet } 2\end{array}$ & 109.8 & 110.1 & 110.0 & 110.0 & Oil-Wet \\
\hline $\begin{array}{c}\text { Water } \\
\text { Droplet } 3\end{array}$ & 107.1 & 106.9 & 107.4 & 107.1 & Oil-Wet \\
\hline \multicolumn{4}{|c|}{ Overall Average Water Droplet Contact Angle $\left(^{\circ}\right)$} & 108.6 & Oil-Wet \\
\hline
\end{tabular}

In this work, IFT measurement between the oil model and washing solution containing bio-surfactant was conducted to determine the CMC of the bio-surfactant (rhamnolipids) in distilled water and seawater where the average CMC was approximately $73 \mathrm{mg} / \mathrm{L}$. This bio-surfactant concentration in the washing solution was used under different conditions to assess the impact.

Tables 6 and 7 show the contact angle results after washing with $\mathrm{WS}_{1}$ and $\mathrm{WS}_{5}$. The addition of bio-surfactant into washing solutions reduced the contact angle from $108.6^{\circ}$ to $73.4^{\circ}$, altering the surface to weakly water-wet. However, washing the oil-wet calcite with distilled water did not show a significant impact, as seen with $\mathrm{WS}_{1}$, where the contact angle reduced from $108.6^{\circ}$ to $94^{\circ}$, altering the surface to neutral-wet. 
Table 6. Contact angle measurements on a calcite surface washed by $\mathrm{WS}_{1}$.

\begin{tabular}{|c|c|c|c|c|c|}
\hline \multicolumn{6}{|c|}{$\mathrm{WS}_{1}$} \\
\hline \#Attempt & Reading $1\left(^{\circ}\right)$ & Reading $2\left({ }^{\circ}\right)$ & Reading $3\left({ }^{\circ}\right)$ & Average Reading Contact Angle $\left({ }^{\circ}\right)$ & Wetting System \\
\hline $\begin{array}{c}\text { Water } \\
\text { Droplet } 1\end{array}$ & 91.7 & 91.9 & 92.1 & 91.9 & Neutral-Wet \\
\hline $\begin{array}{c}\text { Water } \\
\text { Droplet } 2\end{array}$ & 97.8 & 98.4 & 97.2 & 97.8 & Neutral-Wet \\
\hline $\begin{array}{c}\text { Water } \\
\text { Droplet } 3\end{array}$ & 92.6 & 92.3 & 91.9 & 92.3 & Neutral-Wet \\
\hline \multicolumn{4}{|c|}{ Overall Average Water Droplet Contact Angle $\left({ }^{\circ}\right)$} & 94 & Neutral-Wet \\
\hline
\end{tabular}

Table 7. Contact angle measurements on a calcite surface washed by $\mathrm{WS}_{5}$.

\begin{tabular}{cccccc}
\hline \multicolumn{5}{c}{ WS $_{\mathbf{5}}$} \\
\hline \#Attempt & Reading 1 $\left(^{\circ}\right)$ & Reading 2 $\left(^{\circ}\right)$ & Reading 3 $\left(^{\circ}\right)$ & Average Reading Contact Angle $\left(^{\circ}\right)$ & Wetting System \\
\hline $\begin{array}{l}\text { Water } \\
\text { Droplet 1 } \\
\quad \text { Water }\end{array}$ & 70.5 & 69.3 & 69.9 & 69.9 & Slightly Water-Wet \\
$\begin{array}{c}\text { Droplet 2 } \\
\text { Water }\end{array}$ & 76.5 & 76.0 & 75.5 & 76.0 & Slightly Water-Wet \\
$\begin{array}{l}\text { Droplet 3 } \\
\text { Overall Average Water Droplet Contact Angle }\left(^{\circ}\right)\end{array}$ & 74.2 & 73.7 & 74.6 & 74.2 & Slightly Water-Wet \\
\hline
\end{tabular}

Changing the washing solution from distilled water to artificial seawater $\left(\mathrm{WS}_{2}\right)$ had a significant impact on the wettability of the modified calcite, where the measured average contact angle was reduced from $108.6^{\circ}$ to $61.1^{\circ}$. It is worth mentioning that the addition of bio-surfactant to $\mathrm{WS}_{2}$ did not show a significant impact on wettability, with the contact angle only reduced to $58.4^{\circ}$. This means that the presence of salt ions in the water hinders the effect of the bio-surfactant. The summary of all contact angle measurements with their corresponding labels are provided in Table 8.

Table 8. Measured contact angles for all treated calcite surfaces.

\begin{tabular}{ccc}
\hline Label & Contact Angle $\left(^{\circ}\right)$ & Wetting System \\
\hline $\mathrm{K}_{1}$ & 94.0 & Neutral-wet \\
$\mathrm{K}_{2}$ & 73.3 & Water-wet \\
$\mathrm{K}_{3}$ & 61.1 & Water-wet \\
$\mathrm{K}_{4}$ & 58.4 & Water-wet \\
$\mathrm{K}_{5}$ & 54.6 & Water-wet \\
$\mathrm{K}_{6}$ & 41.3 & Water-wet \\
$\mathrm{K}_{7}$ & 91.1 & Neutral-wet \\
$\mathrm{K}_{8}$ & 100.3 & Slightly oil-wet \\
$\mathrm{K}_{9}$ & 75.9 & Water-wet \\
$\mathrm{K}_{10}$ & 85.7 & Slightly water-wet \\
$\mathrm{K}_{11}$ & 91.8 & Neutral-wet \\
$\mathrm{K}_{12}$ & 102.4 & Slightly Oil-wet \\
$\mathrm{K}_{13}$ & 52.0 & Water-wet \\
$\mathrm{K}_{14}$ & 62.6 & Water-wet \\
$\mathrm{K}_{15}$ & 81.7 & Slightly water-wet \\
$\mathrm{K}_{16}$ & 35.5 & Water-wet \\
$\mathrm{K}_{17}$ & 41.9 & Water-wet \\
$\mathrm{K}_{18}$ & 49.0 & Water-wet \\
\hline
\end{tabular}

\subsubsection{The Effect of the Bio-Surfactant and Salinity on the Contact Angle at $25^{\circ} \mathrm{C}$}

The obtained data confirm that rhamnolipids altered the wetting state from oil-wet to water-wet. Figure 1 illustrates the effectiveness of the added rhamnolipids with different salt concentrations at a contact angle of $25^{\circ} \mathrm{C}$. It can be also seen from Figure 1 that the modification of the salt composition with affective ions such as $\mathrm{SO}_{4}{ }^{2-}$ caused a further reduction in the contact angle, with the contact 
angle reduced to $54.6^{\circ}$. The addition of rhamnolipids to modified seawater with three times $\mathrm{SO}_{4}{ }^{2-}$ converted the calcite surface to water-wet with a measured contact angle of $41.3^{\circ}$. Interestingly, the rhamnolipids had a small impact on the contact angle when the salt ions took part in a wettability alteration. This could be due to the rhamnolipids reaching the $\mathrm{CMC}$, therefore no additional reduction was demonstrated in the obtained results.

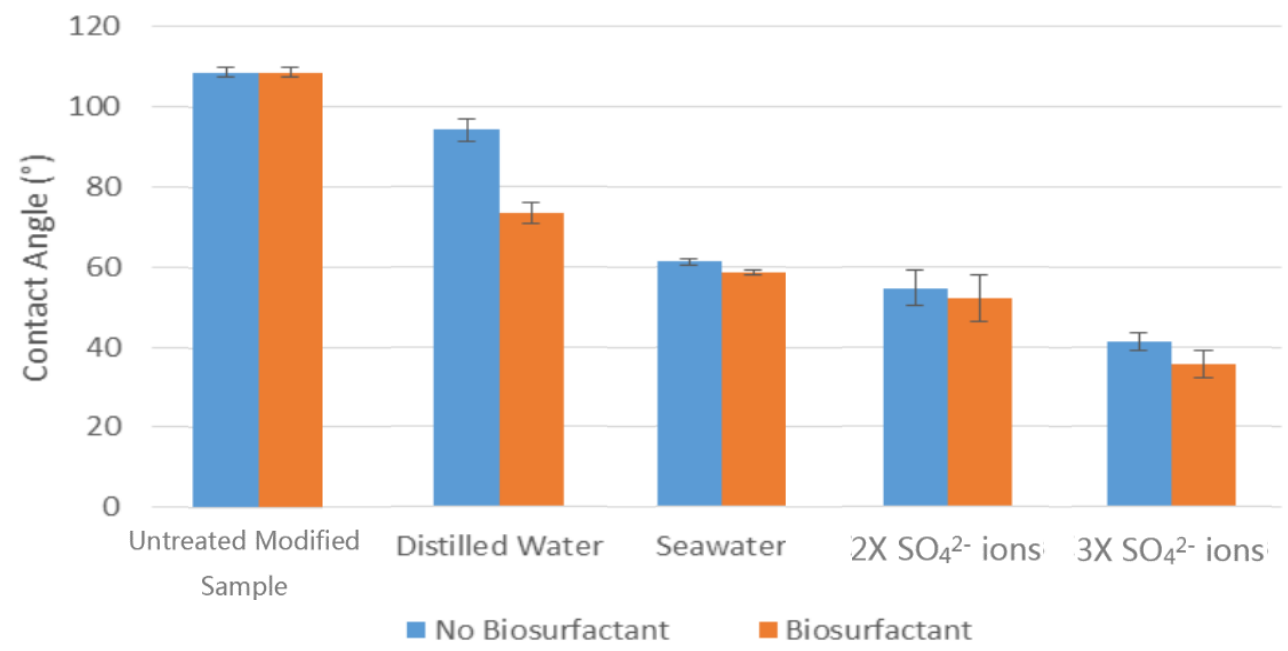

Figure 1. Contact angle measurements for the untreated modified calcite sample and samples treated with different water solutions in the presence and absence of bio-surfactant at $25^{\circ} \mathrm{C}$.

\subsubsection{Effect of Elevated Temperature on Bio-Surfactant Behaviour}

In this section, the effect of temperature on the effectiveness of the bio-surfactant in changing the wetting state of the modified calcite was investigated. The temperature was increased during the washing process to simulate high temperature reservoirs, obtaining the results displayed in Figure 2. In general, it can be seen from Figure 2 that the increase in temperature has a negative impact on the contact angle measurements when the system remains oil-wet.

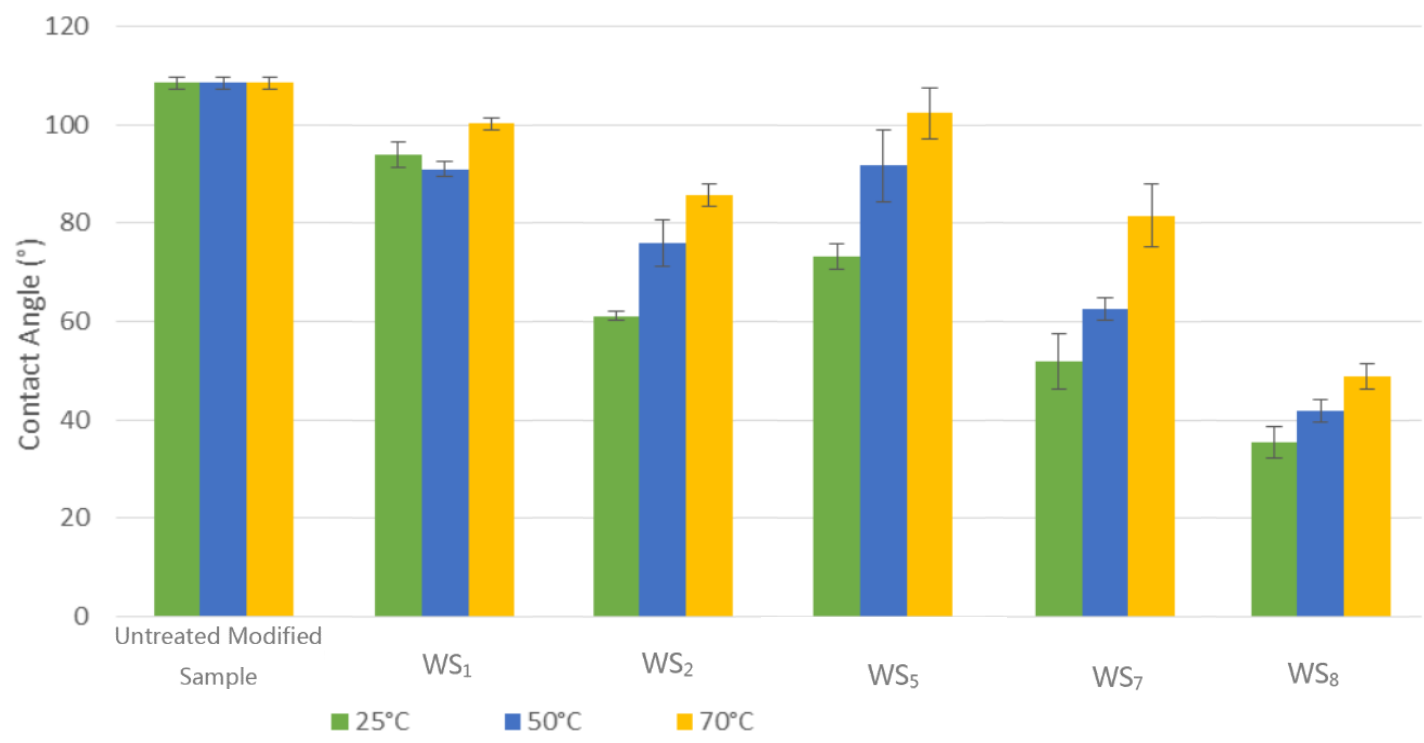

Figure 2. Contact angle measurement at elevated temperature for the untreated modified calcite sample and samples treated with different water solutions.

In detail, the observation of the washing process using distilled water at different temperatures showed that the contact angle measurement at $70{ }^{\circ} \mathrm{C}$ was negligible, as the measurement remained 
around $91.1^{\circ}$ to $100.3^{\circ}$. However, distilled water mixed with bio-surfactant emphasised the additional effect on the wettability. Furthermore, other washing solutions showed a high contact angle measurement at $70{ }^{\circ} \mathrm{C}$, which is inconsistent with the thermal recovery theory used in the tertiary method using external heat to raise the temperature and recover oil residuals. It has been stated that the thermal recovery temperature range can go above $350{ }^{\circ} \mathrm{C}$ [22]. Only increasing this to $70{ }^{\circ} \mathrm{C}$ in this experiment means that we cannot fully assume that a contact angle above $70{ }^{\circ} \mathrm{C}$ will result in a subsequent trend of the contact angle remaining oil-wet as the temperature increases.

According to Pacwa-Płociniczak et al. [6], bio-surfactants are active at extreme $\mathrm{pH}$, salinity, and temperature levels. In contrast, based on Figure 2, it can be seen that the bio-surfactant (rhamnolipids) shows less effectiveness at high temperatures, this pattern might only occur with rhamnolipids and some other specific bio-surfactants. The minor change to water-wet in terms of the wettability could also be a result of the bio-surfactant being degradable, while at high temperatures the bio-surfactant was broken down, therefore not affecting wettability.

Additionally, as it has been shown in Figure 2, the increase in $\mathrm{SO}_{4}{ }^{2-}$ concentration altered the wettability. In fact, by increasing the $\mathrm{SO}_{4}{ }^{2-}$ concentration, a drop pattern in the contact angle measurement was observed. Looking at different concentrations of $\mathrm{SO}_{4}{ }^{2-}$ at increasing temperatures showed a different consistent outline of wettability remaining for oil-water. Strand et al. [23], conducted experiments on the effect of different concentrations of $\mathrm{Ca}^{2+}$ and $\mathrm{SO}_{4}{ }^{2-}$ brine composition mixtures using the oil-wet chalk core flooding method at high temperatures. Their results showed that $\mathrm{SO}_{4}{ }^{2-}$ absorption onto chalk surfaces increased as the temperature and concentration of $\mathrm{Ca}^{2+}$ increased, which is similar to the pattern shown in Figure 2.

\subsection{Interfacial Tension Measurement}

To understand the interaction of different ions and bio-surfactants in washing solutions, the interfacial activities of all the selected solutions were measured. Table 9 shows the reference point of pure n-decane with distilled water and the reduction in IFT when stearic acid was dissolved in n-decane.

Table 9. IFT measurements for reference solutions.

\begin{tabular}{ccccc}
\hline Mixture Label & Reading $\mathbf{1}(\mathbf{m N} / \mathbf{m})$ & Reading $\mathbf{2}(\mathbf{m N} / \mathbf{m})$ & Reading $\mathbf{3}(\mathbf{m N} / \mathbf{m})$ & Average Reading IFT $(\mathbf{m N} / \mathbf{m})$ \\
\hline $\mathrm{M}_{1}$ & 27.1 & 27.0 & 27.1 & 27.1 \\
$\mathrm{M}_{2}$ & 9.3 & 9.6 & 10.0 & 9.6 \\
\hline
\end{tabular}

Similarly to the IFT measurement for the reference case, the IFT for all selected solutions labelled in Table 4 were measured and the results are provided in Table 10.

Table 10. Measured IFT between the model oil and all washing solutions.

\begin{tabular}{cc}
\hline Mixtures Label & IFT (mN/m) \\
\hline $\mathrm{M}_{1}$ & 27.1 \\
$\mathrm{M}_{2}$ & 9.6 \\
$\mathrm{M}_{3}$ & 5.9 \\
$\mathrm{M}_{4}$ & 5.4 \\
$\mathrm{M}_{5}$ & 2.9 \\
$\mathrm{M}_{6}$ & 4.6 \\
$\mathrm{M}_{7}$ & 4.0 \\
$\mathrm{M}_{8}$ & 0.5 \\
$\mathrm{M}_{9}$ & 0.5 \\
$\mathrm{M}_{10}$ & 2.7 \\
$\mathrm{M}_{11}$ & 1.0 \\
$\mathrm{M}_{12}$ & 1.0 \\
$\mathrm{M}_{13}$ & 4.2 \\
$\mathrm{M}_{14}$ & 0.7 \\
$\mathrm{M}_{15}$ & 0.7 \\
\hline
\end{tabular}




\subsubsection{Effect of Bio-Surfactant and Salinity on IFT at $25^{\circ} \mathrm{C}$}

The measured IFT between the model oil and different washing solutions presented in Figure 3 indicate that rhamnolipids had a big impact on the interfacial activity of the oil/water system. The reference sample was measured at $9.6 \mathrm{mN} / \mathrm{m}$ with distilled water and dissolved stearic acid in n-decane. The addition of rhamnolipids to distilled water reduced the IFT by half, to $4.6 \mathrm{mN} / \mathrm{m}$.

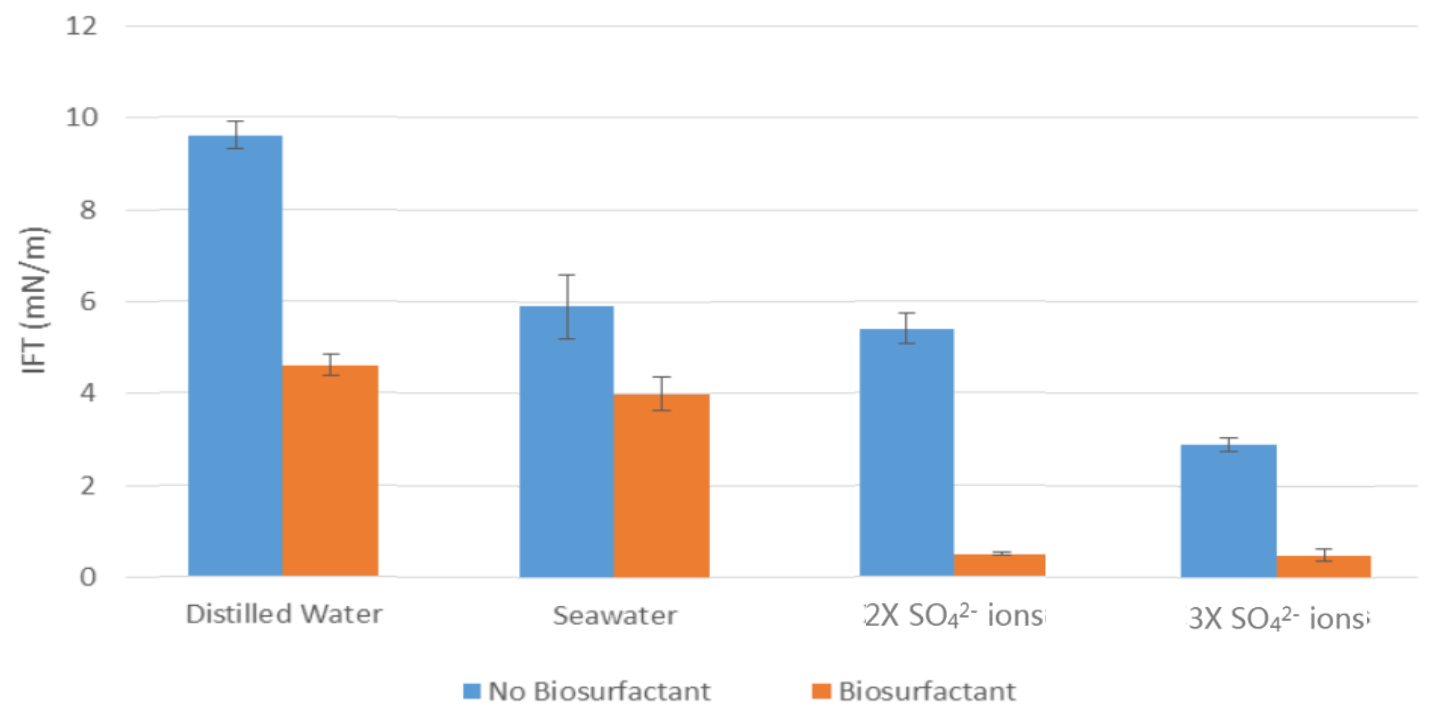

Figure 3. Measured IFT between model oil and different washing solutions at $25^{\circ} \mathrm{C}$.

In terms of seawater with and without a bio-surfactant effect, the results showed that the IFT was reduced to $5.9 \mathrm{mN} / \mathrm{m}$ and $4 \mathrm{mN} / \mathrm{m}$, respectively.

The biggest reduction in IFT was observed by increasing the $\mathrm{SO}_{4}{ }^{2-}$ ions concentration. It should be noted that there was a huge difference between the IFT results with and without addition of the bio-surfactant in presence of $\mathrm{SO}_{4}{ }^{2-}$ ions in water solutions. In fact, by adding bio-surfactant to $2 \mathrm{X}$ $\mathrm{SO}_{4}{ }^{2-}$ ions, there was a significant decline of $4.4 \mathrm{mN} / \mathrm{m}$ in IFT from 5.9 to $0.5 \mathrm{mN} / \mathrm{m}$. Similarly, it was noticeable that there was a gradual decrease in IFT for $3 \mathrm{X} \mathrm{SO}_{4}{ }^{2-}$ ions and bio-surfactant solution.

The IFT has a direct impact on the displacement processes and multiphase flow in porous media. Isehunwa and Olubukola [24] studied the effect of salinity on the IFT oil/brine system of five different Niger Delta reservoirs. Their results indicated a strong relationship between IFT and salinity, with a similar trend in the three experimental reservoirs, revealing a gradual increase in the salt concentration, and the IFT decreasing at different rates. Similar results were reported for IFT reductions when salt concentrations were increased [25].

\subsubsection{Effect of High Temperatures on the Interfacial Activities of Bio-Surfactants}

Figure 4 illustrates the effect of distilled water and different concentrations of $\mathrm{SO}_{4}{ }^{2-}$ ions with bio-surfactant on IFT at high temperature. In terms of distilled water, first the IFT was decreased to $1.9 \mathrm{mN} / \mathrm{m}$ from $25^{\circ} \mathrm{C}$ to $50{ }^{\circ} \mathrm{C}$. Then, by increasing the temperature to $70{ }^{\circ} \mathrm{C}$, an increase in the IFT was observed, showing that the mixture of distilled water and bio-surfactant did not significantly affect the reduction of IFT at high temperatures. However, Abouseoud et al. [26] investigated the bio-surfactant produced by Pseudomonas fluorescens on the surface tension, and their results suggested that when the temperature increased to $100{ }^{\circ} \mathrm{C}$, there was no significant effect on the bio-surfactant's performance and it was still able to reduce surface tension. Varadavenkatesan and Murty [27] observed similar results. 


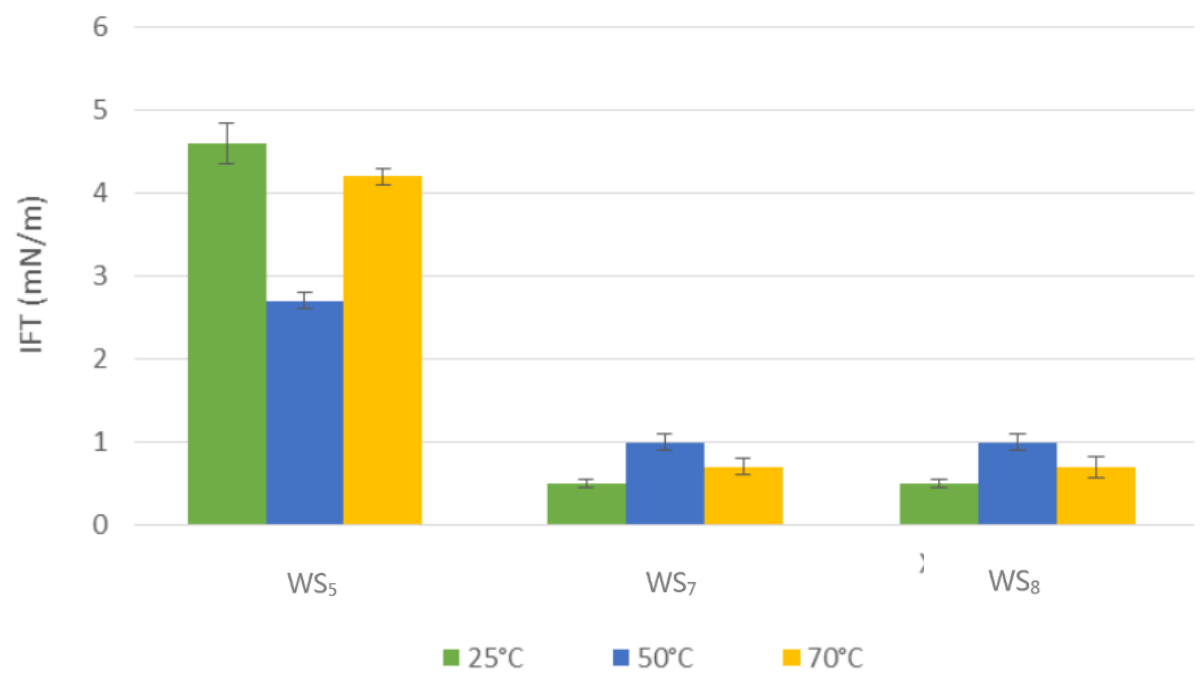

Figure 4. Measured IFT between model oil and washing solutions containing bio-surfactant at elevated temperature.

The highest reduction of IFT was observed when $\mathrm{SO}_{4}{ }^{2-}$ ions added to the water solutions. As is shown in Figure 4, a similar pattern was observed for different concentration of $\mathrm{SO}_{4}{ }^{2-}$ on IFT from 25 to $70{ }^{\circ} \mathrm{C}$ but with higher percentage error in IFT measurements for $3 \mathrm{X} \mathrm{SO}_{4}{ }^{2-}$. In fact, as the temperature increased from $25^{\circ} \mathrm{C}$ to $50^{\circ} \mathrm{C}$, the IFT increased from 0.5 to $1 \mathrm{mN} / \mathrm{m}$. However, as the temperature increased from 50 to $70{ }^{\circ} \mathrm{C}$, the IFT decreased from 1 to $0.7 \mathrm{mN} / \mathrm{m}$. The obtained results in this study are in line with [22] where both increase and decrease in IFT was reported as the temperature increased at the same salt concentration. A conclusive assumption regarding whether temperature has a negative or positive impact on wettability and IFT can be made with regard to the effects of the temperature, which depend on the simulated or actual reservoir rock itself, as the existing research supports both impacts.

\section{Conclusions}

Many research studies have been carried out to find cheap, effective, and environmentally friendly methods to recover the remaining oil residual in the reservoirs. The objective of this research was to obtain more detailed information on the mechanism and effects of a bio-surfactant (rhamnolipids), on interfacial activities of oil/water and wettability of calcium carbonate as a substitute for carbonate rock in presence of salt and at elevated temperature.

The results showed that rhamnolipids is capable to alter the wettability of carbonate rocks and reduce the IFT between oil and water. Rhamnolipids successfully improved the modified oil-wet rock to water-wet rock, and the observation of the IFT showed the existence of a large decrease even under the disturbance of different brine waters. The increase of $\mathrm{SO}_{4}{ }^{2-}$ showed a positive impact on the rocks wettability and IFT, which also helps to lower the IFT and modify the rocks more towards water-wet. The resultant diagrams showed that presence of salt had a greater effect on the contact angle reduction, whereas rhamnolipids were better at reducing the IFT.

The results showed that increasing temperature conditions had undesired effects on the wettability and IFT, as well as on the performance of the bio-surfactant. Even though addition of biosurfactant to water solutions under higher temperature showed the rock surface remaining oil-wet, but the salinity were not affected as the results still demonstrates a reduction in the contact angle and IFT measurement after increase in temperature.

Author Contributions: Supervision, S.R.G., M.I. and D.H.; Writing—original draft, K.E.G.; Writing-review and editing, S.R.G.

Funding: This research received no external funding. 
Acknowledgments: The authors wish to acknowledge Teesside University for providing the materials and facilities to perform the experiments. We also thanks Suet Syn Siew for assisting in executing the experiments in the petroleum laboratory.

Conflicts of Interest: The authors declare no conflict of interest.

\section{References}

1. Kokal, S.; Abdulaziz, A. Enhanced Oil Recovery: Challenges and Opportunities. In World Petroleum Council: Global Energy Solutions; World Petroleum Council: London, UK, 2010; pp. 64-69.

2. Biria, D.; Maghsoudi, E.; Roostaazad, A. Application of Bio-surfactants to Wettability Alteration and IFT Reduction in Enhanced Oil Recovery from Oil-Wet Carbonates. J. Pet. Sci. Technol. 2013, 31, 1267-2013. [CrossRef]

3. Al-Sulaimani, H.; Joshi, S.; Al-Wahaibi, Y.M. Microbial Biotechnology for Enhancing Oil Recovery: Current Developments and Future Prospects. Soc. Appl. Biotechnol. 2011, 2, 147-158.

4. Onbasli, D.; Aslim, B. Bio-surfactant Production in Sugarbeet Molasses by some Pseudomonas spp. J. Environ. Biol. 2009, 30, 161-163. [PubMed]

5. Rikalovic, M.G.; Vrvic, M.M.; Karadzic, I.M. Rhamnolipid Bio-surfactant from Pseudomonas Aeruginosa: From Discovery to Application in Contemporary Technology. J. Serb. Chem. Soc. 2015, 80, 279-304. [CrossRef]

6. Pacwa-Płociniczak, M.; Płaza, G.A.; Piotrowska-Seget, Z.; Cameotra, S.S. Environmental Applications of Bio-surfactants: Recent Advances. Int. J. Mol. Sci. 2011, 12, 633-654. [CrossRef] [PubMed]

7. Anderson, W.G. Wettability Literature Survey-Part 5: The Effects of Wettability on Relative Permeability. J. Pet. Technol. 1987, 39, 1453-1468. [CrossRef]

8. Al-Sulaimani, H.; Al-Wahaibi, Y.; Al-Bahry, S. Residual-Oil Recovery through Injection of Bio-surfactant, Chemical Surfactant, and Mixtures of Both under Reservoir Temperatures: Induced-Wettability and Interfacial-Tension Effect. Soc. Pet. Eng. 2012, 15, 210-217.

9. Sarafzadeh, P.; Niazi, A.; Oboodi, V.; Ravanbakhsh, M.; Ayatollahi, S. Investigating the Efficiency of MEOR Processes using Enterobacter Cloacae and Bacillus Stearothermophilus SUCPM\#14 (Bio-surfactant-Producing Strains) in Carbonated Reservoirs. J. Pet. Sci. Eng. 2014, 113, 46-53.

10. Chandankere, R.; Yao, J.; Masakorala, K.; Chan, Y. An Efficient Bio-surfactant-Producing and Crude-oil Emulsifying Bacterium Bacillus Methylotrophicus USTBa Isolated from Petroleum Reservoir. Biochem. Eng. J. 2013, 74, 46-53. [CrossRef]

11. Shibulal, B.; Al-Bahry, S.N.; Al-Wahaibi, Y.M.; Elshafie, A.E. Microbial Enhanced Heavy Oil Recovery by the Aid of Inhabitant Spore-Forming Bacterial: An Insign Review. Sci. World J. 2014, 1-12. [CrossRef] [PubMed]

12. Moeini, F.; Hemmati, A.; Ghazanfari, M.H.; Masihi, M.; Ayatollahi, S. Toward Mechanistic Understanding of Heavy Crude oil/brine Interfacial Tension: The roles of Salinity, Temperature and Pressure. Fluid Phase Equilib. 2014, 375, 191-200. [CrossRef]

13. Hamouda, A.A.; Gomari, K.A.R. Effect of Fatty Acids, Water Composition and pH on the Wettability. J. Pet. Sci. Eng. 2006, 50, 140-150.

14. Hamouda, A.A.; Gomari, K.A.R. Influence of Temperature on Wettability Alteration of Carbonate Reservoirs. Soc. Pet. Eng. 2006, 4, 1-12.

15. Nasralla, R.A.; Bataweel, M.A.; Nasr-El-Din, H.A. Investigation of Wettability Alteration and Oil-Recovery Improvement by Low-Salinity Water in Sandstone Rock. J. Can. Pet. Technol. 2013, 52, 144-154. [CrossRef]

16. Olalekan, A.O.; Ezra, A.A. The Effect of Water Salinity on Permeability of Oil Reservoir. In Proceedings of the 2nd International Conference on Research in Science, Engineering and Technology, Hong Kong, China, 10-12 September 2014; pp. 78-80.

17. Zhang, P.; Austad, T.; Tweheyo, M.T. Wettability Alteration and Improved Oil Recovery by Spontaneous Imbibition of Seawater into Chalk: Impact of the Potential Determining Ions $\mathrm{Ca}^{2+}, \mathrm{Mg}^{2+}$, and $\mathrm{SO}_{4}{ }^{2-}$. Colloids Surf. A Physicochem. Eng. Asp. 2007, 301, 199-208. [CrossRef]

18. Sheng, J.J. Enhanced Oil Recovery, Field Case Studies, 1st ed.; Gulf Professional Publishing: Houston, TX, USA, 2013.

19. Hamouda, A.A.; Karoussi, O. Effect of Temperature, Wettability and Relative Permeability on Oil Recovery from Oil-wet Chalk. Energies 2008, 1, 19-34. [CrossRef] 
20. Pattanathu, R.; Godfrey, P.; Vincent, A.; Zulfiqur, A. Production of Rhamnolipid Biosurfactants by Pseudomonas Aeruginosa DS10-129 in a Microfluidic Bioreactor. Biotechnol. Appl. Biochem. 2010, 55, $45-52$.

21. Kester, D.R.; Duedall, I.W.; Connors, D.N.; Pytkowicz, R.M. Preparation of Artificial Seawater. Limnol. Oceanogr. 1967, 12, 176-179. [CrossRef]

22. Sheng, J.J. Modern Chemical Enhanced Oil Recovery: Theory and Practice; Elsevier: Amsterdam, The Netherlands, 2011.

23. Strand, S.; Hognesen, E.J.; Austad, T. Wettability Alteration of Carbonates-Effects of Potential Determining Ions. Colloids Surf. A Physicochem. Eng. Asp. 2006, 275, 1-10. [CrossRef]

24. Isehunwa, S.O.; Olubukola, O. Interfacial Tension of Crude Oil-Brine System in the Niger Delta. Int. J. Res. Rev. Appl. Sci. 2012, 3, 460-465.

25. Wu, Z.; Yue, X.; Cheng, T.; Yu, J.; Yang, H. Effect of Viscosity and Interfacial Tension of Surfactant-Polymer Flooding on Oil Recovery in High-Temperature and High-Salinity Reservoirs. J. Pet. Explor. Prod. Technol. 2014, 4, 9-16. [CrossRef]

26. Abouseoud, M.; Maachi, R.; Amrane, A. Bio-surfactant Production from Olive Oil by Pseudomonas Fluorescens. In Communicating Current Research and Educational Topics and Trends in Applied Microbiology; Méndez-Vilas, A., Ed.; Formatex: Badajoz, Spain, 2007; pp. 340-347.

27. Varadavenkatesan, T.; Murty, V.R. Production of a Lipopeptide Bio-surfactant by a Novel Bacillus sp. and Its Applicability to Enhanced Oil Recovery. ISRN Microbiol. 2013. [CrossRef] [PubMed]

(C) 2018 by the authors. Licensee MDPI, Basel, Switzerland. This article is an open access article distributed under the terms and conditions of the Creative Commons Attribution (CC BY) license (http:/ / creativecommons.org/licenses/by/4.0/). 